\title{
Editorial
}

\section{Terrorism and international finance: Recent developments from the perspective of international law}

Just 13 days after the USA was attacked by terrorists, President Bush signed an Executive Order $^{1}$ freezing the assets of 27 organisations and persons known to be linked to Al-Q'aeda and suspected of funding terrorism. Significantly, he called on foreign banks to follow his example, or have their US assets frozen. He said that this war was to be a conflict "without battlefields and beachheads'. In a real sense, it was launched not on the battlefield, but in the financial field. Since then, the USA has made it a policy objective to deny terrorist groups access to the international financial system, to impair the ability of terrorists to fund raise, and to expose, isolate and incapacitate the financial networks of terrorists. Many more names followed. The objective has been pursued across the financial community without regard to frontiers, and a new reality is rapidly emerging on the financial scene.

Inevitably, the background lies in the development of modern finance and the rise in global capital. One result of globalisation and technology is that it is much easier to move money around. The figures are very large. In April 2000, the Bank of England estimated the average daily turnover in the London foreign exchange market alone at $\$ 637 \mathrm{bn} .^{2}$ At the consumer level, credit and debit cards provide ready access to funds internationally. As the financial system grew, policy makers began to appreciate its potential as a means of exerting pressure. Conversely, the need to prevent abuse also became apparent. I will take as a starting point December 1985, when terrorist attacks took place against Rome and Vienna airports. President Reagan cited these attacks to justify the imposition of sanctions on Libya, and by an executive order made on 8th January, 1986, blocked Libyan assets held in the USA and US dollar deposits in US banks' overseas branches. The order followed the same pattern as the freeze that had been imposed on Iranian assets after the hostage crisis of 1979-81. That long running matter remains unresolved, probably to Iran's disadvantage. The US-Iran claims tribunal continues its work to this day. But these were unilateral sanctions. Particularly in the case of Libya, their effectiveness was undermined by the refusal of foreign courts to recognise their extraterritorial effect, even with regard to US dollar deposits held in local branches of US incorporated banks. ${ }^{3}$

Compare the position at the international level. On 21st December, 1988, Pan Am flight 103 was brought down by a bomb over Lockerbie in Scotland. The finger of suspicion again pointed to Libya. This time, there was sufficient consensus for international sanctions. The process was not speedy. Financial sanctions were not imposed until 11th November, 1993. ${ }^{4}$ But once imposed, UN sanctions did not suffer from the inherent weakness of unilateral sanctions. They were applied, at least in principle, so as to freeze assets internationally, depending upon the effectiveness of
Journal of International Banking Regulation, Vol. 4, No. 1, 2002 , pp. 7-12

(C) Henry Stewart Publications, 1465-4830 
compliance by member states. And in the case of Pan Am flight 103, they did lead to the trial and conviction of suspects. There are currently 11 Security Council Sanctions Committees, each concerned with sanctions against particular states, though not necessarily related to terrorism. Speaking on 17th April, 2000, the Secretary-General said that 'the world may well conclude that the use of sanctions as an instrument of the Security Council and of Member States, was one of the defining characteristics of the post-Cold War era'. It had certainly been demonstrated that specifically directed financial sanctions can produce results. That lesson was put into effect following 11th September.

Policy makers found another analogy close to hand, in the form of the rules banning money laundering. Again, there are comparisons with terrorism, particularly in the sense of clandestine networks operating across borders. From an early stage, it was recognised that money laundering could only be tackled effectively at the international level. A landmark is the UN Convention against Illicit Traffic in Narcotic Drugs and Psychotropic Substances concluded in Vienna in 1988. In some countries, anti-money laundering legislation remains limited to the proceeds of drug dealing, whereas in others it has been extended to other forms of criminal activity, including terrorism. At the same time as putting in place legal measures, there were practical steps taken to monitor and promote them. The Financial Action Task Force on Money Laundering (FATF) was established by the G-7 Summit that was held in Paris in 1989. At the time, this tended to be written off as yet another well-meaning international initiative. In fact, the FATF has been quite effective. Criticism now tends to come from offshore financial centres, which feel that the FATF brings pressure to bear on them without proper international legitimacy. Whatever the force of that criticism, the FATF has actively promoted tighter safeguards against money laundering both at the government level and on financial institutions. The latter have had to take note, partly because of pressure from regulators, and partly because of public opinion and the threat of lawsuits.

It is one thing putting money laundering safeguards in place. But do they actually work? At an operational level, the methodology is quite crude. Financial institutions apply 'know your customer' standards at the time accounts are opened. They use operational indicia for the detection and reporting of suspicious transactions. At the same time, many large financial institutions now have sophisticated software to help them do the job. This software analyses accounts for movements outside the normal patterns. Once a suspicious transaction is detected, a report is filed with the authorities and the matter generally languishes. This is hardly surprising when one considers that during 2000, a total of 18,408 disclosures were made in the UK alone, ${ }^{5}$ and the numbers in the USA are far higher. If investigated, most of these would turn out not to involve criminal activity. While there is no evidence that I am aware of that the crackdown on money laundering has made significant inroads into the narcotics trade, it would be wrong to underestimate the cumulative importance of these initiatives. In my experience, banks are increasingly concerned to observe proper money laundering standards, if only as a matter of self-protection. These steps go hand in hand with inroads on banking secrecy and the closing down of tainted financial institutions.

This should result in a cleaner financial system over the medium to long term. But this is not a sufficient response to the events of 11th September. Nevertheless, it is an important part of the overall picture. At an extraordinary Plenary on the Financing of 
Terrorism held in Washington, DC on 29th and 30th October, 2001, the FATF expanded its mission beyond money laundering, stating that it will now also focus its energy and expertise on the worldwide effort to combat terrorist financing. It has issued Special Recommendations to deny terrorists and their supporters access to the international financial system. It intends to apply these to non-members around the world as well as to members. Again, it would be wrong to underestimate the importance of this initiative. There is very considerable momentum behind these efforts. Having said that, there are also important differences between money laundering and terrorist funding. Money laundering is concerned with the proceeds of crime. If account-opening procedures were sufficiently rigorous, in theory criminals could be deprived of access to the financial system. In the case of terrorist funding, the perpetrators may have no criminal connections in the conventional sense. Indeed a chilling feature of the attacks on 11th September was the apparent ordinariness of the people who carried them out. There may be no proceeds of crime as such. The amounts concerned may be for the operations of a small group of people. The smaller the sums involved, the greater the difficulty of detection. So techniques developed for the detection of money laundering are unlikely to be enough in themselves.

Having said something about the practical difficulties, I want to turn to the legal framework. Concern about terrorist funding has been around for some time. The UN International Convention for the Suppression of the Financing of Terrorism of 9th December, 1999 was the product of General Assembly concern about the need for measures to counteract the movement of funds suspected of terrorist purposes without impeding free capital movements. The Convention obliges states to create var- ious offences relating to the funding of terrorism and to take measures for the identification, detection, freezing and seizure of such funds and the proceeds of terrorism. For example Article 8 provides that:

'Each State Party shall take appropriate measures, in accordance with its domestic legal principles, for the identification, detection and freezing or seizure of any funds used or allocated for the purpose of committing [terrorist offences] as well as the proceeds derived from such offences, for purposes of possible forfeiture.'

The Convention is restricted to terrorist acts with an international element. It is a useful and in many ways impressive piece of work, but it is still not in force.

At the international level, there were also measures taken against the Taliban and Osama bin Laden, namely Security Council Resolutions 1267 of 1999 and 1333 of 2000 respectively. These measures were to assume particular significance after 11th September. They were imposed after the US embassy bombings in East Africa in 1998. In both cases, they included a financial freeze. ${ }^{6}$

The atrocity on 11th September, however, had an immediate and galvanising effect. On 28th September, acting under Chapter VII of the UN Charter, the Security Council decided that all states should criminalise the funding of terrorism, and should 'freeze without delay funds and other financial assets or economic resources' of terrorists, entities owned by terrorists and those acting for them (SC Resolution 1373 of 28th September, 2001). This is now the most important international instrument as regards terrorism and finance. The obligation to freeze terrorist assets is unqualified and of universal application. The Security Council also established a Counter-Terrorism Committee to 
monitor compliance with Resolution 1373. Over 100 states have reported to it on the implementation of the resolution. The Committee's role is limited, however, and it has made it clear that it will not get into scrutinising legislation. ${ }^{7}$

Resolution 1373 was widely put into effect by implementing measures in domestic law. ${ }^{8}$ It was also the spur to new legislation dealing with terrorism generally. ${ }^{9}$ In some countries the process has been controversial. In India, the Prevention of Terrorism Ordinance passed onto the statute book only after an extraordinary joint sitting of both Houses of Parliament on 26th March, 2002.

From the financial perspective, by far the most important domestic measures have been those introduced in the USA. Right from the start, the Administration was determined to make sure that they were effective internationally. When the President issued his Executive Order of 24th September blocking terrorist assets, he stated that the order broadened existing authority by establishing the ability of the US 'to block the US assets of, and deny access to US markets to, those foreign banks that refuse to freeze terrorist assets'. This was taken one stage further on 26th October, 2001 when he signed into law the Uniting and Strengthening America by Providing Appropriate Tools Required to Intercept and Obstruct Terrorism Act of 2001, known by its acronym, the 'Patriot Act'. Though this Act is primarily a domestic US measure, it has significant implications for non-US financial institutions, including those without a branch or subsidiary operating in the USA. For example, a US bank that maintains a correspondent account in the USA for a foreign bank must obtain certain information regarding that bank, including information regarding the identity of its owners and its US-based agent for the service of legal process. The latter provision may be highly effective. If a foreign party appoints an agent for the service of legal process, it renders itself susceptible to the jurisdiction of the local courts. Powers are given to prohibit, or impose conditions upon, correspondent accounts in the USA of foreign banks. US banks are prohibited from having correspondent accounts with so-called 'shell banks'.

The potential effect of these measures can be easily demonstrated. Any bank of any size must be able to process US dollar payments on behalf of its customers. In the case of banks without a presence in the USA, this is done by means of correspondent accounts. It follows that a bank identified by the US authorities as being in breach of the rules regarding terrorist funding is at risk of losing access to its US correspondents, with what that implies for its business. The strengthening of the de facto power of the USA over the international financial system is an effect of 11th September which was presumably neither foreseen nor intended by its perpetrators.

I mentioned earlier the differences between money laundering and terrorist funding. Prevention of the latter has required a new approach. The most significant step has been to name terrorist suspects and circulate the lists to financial institutions for appropriate action. Of course, naming individuals does not derogate from the general duty to freeze terrorist assets, whether the suspect's name appears on an official list or not. The basis for this duty lies in international law, as shown by Security Council Resolution 1373 of 28th September, 2001. In practice, however, the lists have been very significant. There is no direct parallel here in the case of money laundering. There are no lists of money laundering suspects issued by the authorities, at least not publicly. The terrorist suspect lists in fact originated in the United Nations. Following the financial freeze imposed by the Security Council on the Taliban and Osama bin Laden, a 
Security Council Sanctions Committee was set up to designate persons and undertakings within the freeze. This it did, and by March 2001, it had produced a consolidated list. The names on it included associated bodies, as well as individuals. The list was circulated to banks by the appropriate national authorities, and where identified, accounts were frozen.

Once Osama bin Laden had been implicated in the 11th September attacks, and the Taliban for giving him sanctuary, the position changed rapidly. The Sanctions Committee added numerous names to the list under the authority of the Security Council Resolutions of 1999 and 2000. At the same time, national authorities began to issue their own lists. Particularly important are the lists from time to time published by the Office of Foreign Assets Control, which is an office of the US Department of the Treasury. The current list runs to 27 pages and includes thousands of names of individuals and organisations suspected of terrorism worldwide. It is not limited to suspects designated by the UN Sanctions Committee, though it can be said to follow in the spirit of Resolution 1373, which of course is not specific to the Taliban and Osama bin Laden. Other bodies round the world have issued their own lists. In practice, much of the efforts of financial institutions has been concentrated in complying with these lists.

So the lists are important. In theory, they represent an advance on money laundering measures, because individuals and organisations are named. The issue is not whether a particular transaction is suspicious. Any financial dealings with those named are absolutely prohibited. In fact, however, the position is considerably more complicated. I want to make a number of observations in this regard.

- The first relates to the proliferation of lists. There are lists issued by the
United Nations and the European Union, as well as by national authorities. Because these lists are not always identical, there is a risk of confusion. This is probably inevitable given the nature of the process. Nevertheless, in principle it would be desirable to standardise the process as far as possible. This is not merely a matter of convenience to financial institutions. Clearly if confusion reduces effectiveness, this is to be avoided.

- The second point relates to the names on the lists. There are individuals who maintain that they have been wrongly identified as terrorist suspects. One case involving a Saudi businessman received considerable publicity at the end of last year. A legal challenge was mounted by the individual concerned against the inclusion of his name on a list issued by the Bank of England. That list was itself based on a list issued by the US Treasury. So far, the issue has not been resolved. Without compromising the effectiveness of the measures, the risk of injustice should be acknowledged, particularly since there is no international tribunal in which to have doubtful cases reviewed, so that the onus is on national authorities.

- The third point relates to identification. It has become clear that naming suspects is a very imprecise tool. There are a number of reasons for this. As well as the fact that numerous suspects have one or more aliases, there are different spellings of the same name and ignorance of national naming conventions. Also, some of the names on the lists are common surnames. In some cases, just a few names on a list match exactly hundreds of names on the database of customers of the banks concerned. No other information as to the people concerned was made available by the authorities to assist in the 
identification process. The result is that listing is not an automatic panacea, since banks still have to make judgments as to the identity of customers. In most cases, it will be obvious whether the customer concerned is a terrorist or not. But there are marginal cases, and the consequences of making a mistake may be serious.

- The fourth point relates to territorial reach. It might be thought that it would be sufficient for banks to abide by the lists issued by their own national authorities. In practice, this is far from being the case. For one thing, banks operating in more than one country inevitably find their operations the subject of lists published by more than one authority. For another, no bank could safely ignore the fact that a customer had been listed as a terrorist suspect by a reputable foreign authority. On the other hand, if a bank is to take action on this basis, it will require justification under domestic law. If justification cannot be found in statutory provisions relating to terrorism, or otherwise in legal principle, the prohibition of a foreign authority will have no legal effect.

So to conclude, it can been seen that the financing of terrorism is prohibited under international law. In practice, however, the prohibition has been left to the financial institutions to police. This has led to certain tensions. Banks are not best equipped to act as amateur detectives. They do not see that as their role, and nor do their customers, the vast majority of whom are not involved in terrorism. The fact that of necessity banks have had to adopt this role should not obscure the point that genuine issues do arise as to their customers' rights to privacy, property and due process. There is clearly a balance to be achieved here. Are there any wider implications in the longer term for the financial system? One we should guard against is the undue restriction of access to the financial system to the disadvantage of institutions in developing countries. Finally, how effective has the prohibition been? Substantial sums have been frozen in various countries, but I do not think that this is the real measure of effectiveness. My own view is that over time the prohibition of terrorist funding will become increasingly effective, provided that states continue to make it a priority. At present, all the signs are that they will.

William Blair QC

Member of MOCOMILA, Barrister

3 Verulam Buildings, Gray's Inn

London WC1R 5NT

\section{References}

(1) Executive Order 13224 of 24th September, 2001.

(2) Fact Sheet on the Foreign Exchange Market published by the Bank of England.

(3) See Libyan Arab Foreign Bank v. Bankers Trust Co [1989] QB 728, a decision of the English courts.

(4) S/RES/883 (1993).

(5) NCIS Press Release, 1st August, 2001.

(6) See also Council Regulation (EC) No. 467/2001 [2001] OJ L67/1, Art. 2, imposing a freeze across the European Union.

(7) Press briefing by the Chairman, 19th October, 2001.

(8) In the UK, see The Terrorism (United Nations Measures) Order 2001, 2001 SI No. 3365, made by order in council under the United Nations Act 1946. See now 2002 S1 No. 111. On 27th December, 2001, the European Community passed Council Regulation (EC) No.2580/ 2001 [2001] OJ L334/70 to the same effect.

(9) In the UK, the Anti-Terrorism, Crime and Security Act 2001. See, generally, Cranston, 'Principles of Banking Law', 2nd edn, to be published in 2002 .

This Editorial is based on a paper presented to the 70th Conference of the International Law Association. 